\title{
Evaluation of epidemiological characteristics of pelvic fractures
}

\section{Pelvik kırıkların epidemiyolojik özelliklerinin değerlendirilmesi}

\author{
Nezih KAVAK ${ }^{*}$ ○, Evrim DUMAN² $\square$, Mesut TIKMAN³ $\square$, Ayhan Sümer YAMAN ${ }^{4} \square$
}

'University of Health Sciences Dışkapı Yıldırım Beyazıt Training and Research Hospital, Emergency Department, Ankara / TURKEY

2University of Health Sciences Dışkapi Yıldırım Beyazıt Training and Research Hospital, Orthopedic and Traumatology Department, Ankara / TURKEY

${ }^{3}$ KarabükUniversity KarabukTraining and Research Hospital Orthopedics and Traumatology, Karabuk/TURKEY ${ }^{4}$ Ankara Training and Education Hospital Department of Emergency Medicine, Ankara/ TURKEY

\begin{abstract}
Aim: To investigate the epidemiological characteristics of patients with pelvic fractures.

Material and Methods: We evaluated age, gender, comorbid disease, admission season, mechanisms of the injury, type of the fractures (Young Burgess classification), associated injuries, and mortality of patients with pelvic fractures in the emergency department (ED).

Results: Of the 919 patients included in the study, 307 (33.4\%) were female and 612 (66.6\%) were male. The mean age was $36,5 \pm 14,82(18-80)$ years. The mean age of males was $35.1 \pm 13.63$ years, and it was $39.2 \pm 16.63$ years for females. Of the males, $46.4 \%$ were in the $28-37$ years range. Comorbid diseases were found in 254 (27.6\%) patients. Of the patients, $302(32.9 \%)$ were admitted in winter and $285(31 \%)$ in summer. It was mostly occurred due to automobile accidents 268 (29.2\%), followed by falls from height 211 (23\%). Automobile accidents were most common in the winter season, while falls from height was more common in the summer. While automobile accidents, falls from height, motorcycle accidents were more common in males compared to females, falls from own height, pedestrians hit by a car, and other injuries were observed more frequently in females than males $(p<0.001)$. While the mean age of females fell from their own height was 62.79 years, it was 68.46 years for males. $423(46 \%)$ lateral compression 1 was detected most frequently. It was accompanied by abdominal trauma in 321 (34.9\%) patients and head trauma in 299 (32.5\%) patients. Eighty (8.7\%) patients died in ED.
\end{abstract}

Conclusion: The most common mechanisms of pelvic fracture injury are automobile accidents and falls. Associated injuries are frequently observed.

Keywords: pelvic fracture; epidemiology; type of fracture; associated injury

Corresponding Author*: Nezih Kavak, University of Health Sciences Dışkapı Yıldırım Beyazıt Training and Research Hospital, Emergency Department, Ankara / TURKEY

E-mail: nezih_kavak@hotmail.com

ORCID: 0000-0003-2751-0046

Recevied: 24.05.2021 accepted: 26.07.2021

Doi: $10.18663 /$ tjcl.941517 


\section{Öz}

Amaç: Pelvik kırıklı hastaların epidemiyolojik özelliklerini araştırmak.

Gereç ve Yöntemler: Acil serviste (AS) pelvik kırıklı hastaların yaşı, cinsiyeti, komorbid hastalığı, başvuru mevsimi, yaralanma mekanizmaları, kırık tipi (Young Burgess sınıflaması), ilişkili yaralanmaları ve mortaliteleri değerlendirildi.

Bulgular: Çalışmaya alınan 919 hastanın 307'si $(\% 33,4)$ kadın ve 612'si $(\% 66,6)$ erkek idi. Ortalama yaş 36,5 $\pm 14,82(18-80)$

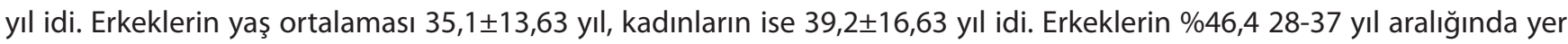
almakta idi. $254(\% 27,6)$ hastada komorbid hastalık bulunmaktaydı. $302(\% 32,9)$ hasta kış, $285(\% 31)$ hasta yaz mevsiminde başvurmuştu. En sık otomobil kazaları 268 (\%29,2) sonra yüksekten düşmeler 211 (\%23) nedeni ile meydana gelmişti. Otomobil kazaları en sık kış, yüksekten düşmeler ise yaz mevsiminde daha sıktı. Otomobil kazaları, yüksekten düşmeler, motorsiklet kazaları erkeklerde kadınlardan daha sık iken, kendi seviyesinden düşmeler, araç dışı trafik kazaları, diğer yaralanmalar kadınlarda erkeklerden daha sık olarak izlendi $(p<0,001)$. Kendi seviyesinden düşen kadınların yaş ortalaması 62,79 yıl iken, erkeklerin 68,46 yıl idi. En sık 423 (46\%) lateral kompresyon 1 tespit edildi. 321 (\%34,9) hastada abdominal travma, $299(\% 32,5)$ hastada kafa travması eşlik etmekteydi. Seksen $(8.7 \%)$ hasta AS'de öldü.

Sonuç: Pelvik kırık yaralanmasının en yaygın mekanizmaları otomobil kazaları ve düşmelerdir. Bu kırıklara eşlik eden yaralanmalar sıktır.

Anahtar kelimeler: pelvik kırık; epidemiyoloji; kırık tipi; ilişkili yaralanma

\section{Introduction}

Pelvic fractures are severe injuries that take an important place among the trauma patients presenting to the emergency department (ED). Pelvic fractures are still a significant cause of trauma-related mortality, in contrast to the decrease observed in the mortality of trauma victims [1]. Approximately $4-9 \%$ of patients with blunt trauma and $1.5-3 \%$ of skeletal system injuries are constituted by pelvic fractures $[2,3,4]$.

Although it usually occurs due to high-energy trauma, it can also occur due to low-energy trauma in the elderly. Depending on the mechanism of the trauma, pelvic fractures have a wide clinical spectrum from life-threatening complete pelvic detachment to simple non-severe fractures [5,6]. Moreover, other systemic injuries frequently associate these fractures [4]. A small part of publications on pelvic fractures, which pose a significant burden on patients and the health system in physical, psychological, social, and financial terms, are related to epidemiological data $[7,8]$. In Turkish society, on the other hand, recent epidemiological data on this issue are insufficient. This study aims to evaluate the epidemiology of patients with pelvic fractures admitted to the ED in a tertiary hospital in Ankara.

\section{Materials and Methods}

Patient population and study design

The local ethics committee approved this retrospective study. A patient over 18 years of age with a pelvic fracture due to blunt trauma was evaluated in the ED of a tertiary hospital between December 2015 and December 2020.

The exclusion criteria were as follows: (1) those with penetrating trauma; (2) those who refused treatment; (3) those who were referred to another hospital; (4) those with deficiencies in hospital records; (5) those who were brought to ED dead were excluded from the study.

The collected data included: age, gender, comorbid disease admission season, mechanisms of the injury, type of the fractures, associated injuries, and mortality.

All patients get a pelvic X-ray and/or a computed tomography (CT) scan. Fractures were classified into types according to the Young and Burgess classification. There are four types of injuries according to this classification; lateral compression (LC), anteroposterior compression (APC), vertical shear (VS), and combined (CM). LC injuries are classified into $L C 1, L C 2$, and LC3, APC injuries are classified into APC1, APC2, and APC3 [9].

Associated injuries were evaluated as head, maxillofacial, chest, spine, abdomen, genitourinary, upper, lower extremity, pelvic haemorrhage, intraabdominal haemorrhage.

\section{Statistical Analysis}

Statistical analysis was performed using Statistical Package for the Social Sciences, Version 22.0 (SPSS Inc., Chicago, IL). In the study, mean \pm standard deviation was given for numerical data as descriptive statistics, while number ( $n$ ) and percentage 
(\%) were given for categorical data. Pearson's Chi-square test was used to compare categorical data. Whether there is a difference between gender in terms of age was analyzed with Student's t-test. $P<0.05$ was considered statistically significant.

\section{Results}

During the study period, 11,459 patients presented with ED due to blunt trauma. Pelvic fractures were detected in 1,048 of them. The incidence of pelvic fractures was $9.1 \%$.

Of the 919 patients, 307 (33.4\%) were female, and 612 (66.6\%) were male. The mean age was $36,5 \pm 14,82$ years and range 18 80. A statistically significant difference was found in male and female patients in terms of mean age $(p<0.001)$. The mean age of males was $35.1 \pm 13.63$ years, while the mean age of females was $39.2 \pm 16.63$ years. Of the males, $46.4 \%$ were in the 28-37 age/year range (Figure 1).

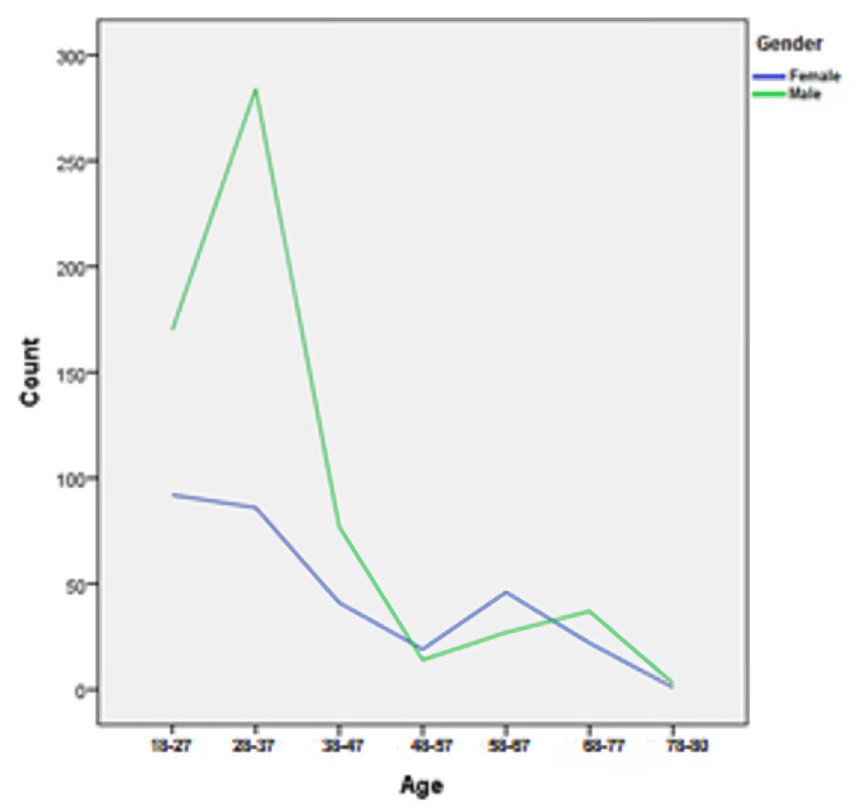

Figure 1: Age distribution of males and females with pelvic fractures. Comorbid diseases were found in 254 (27.6\%) patients. There were 47 (5.1\%) patients with one comorbid disease and 207 (22.5\%) patients with more than one comorbid disease. The most common comorbid diseases were hypertension with 80 (8.7\%), diabetes mellitus with 60 (6.5\%), cardiovascular disease with 46 (5\%), chronic obstructive pulmonary disease with 29 (3.2\%), dementia with 23 (2.5\%), and other diseases with $16(1.7 \%)$, respectively. There was no statistically significant difference between males and females in terms of comorbid diseases ( $p>0.05)$.

Of the patients, 302 (32.9\%) were admitted in winter, 235 (25.6\%) in autumn, 285 (31\%) in summer and 97 (10.5\%) in spring season.
Among the mechanisms of the injury, the most common were automobile accidents 268 (29.2\%), then falls from height 211 (23\%) (Figure 2).

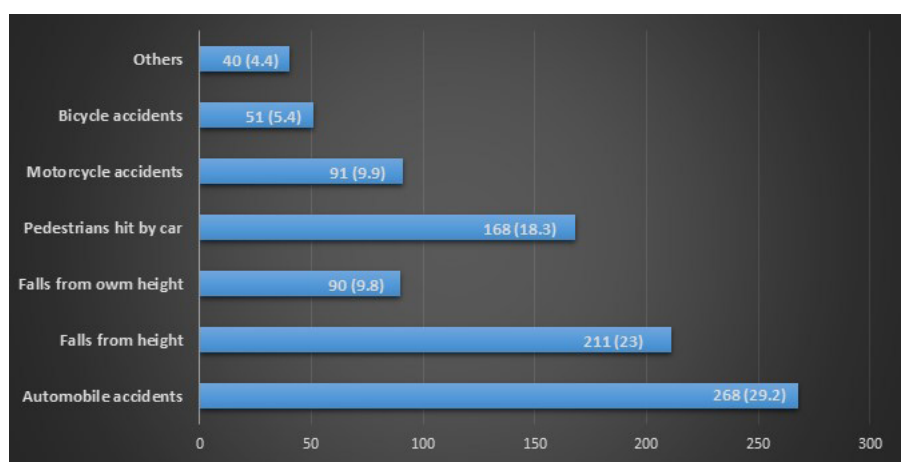

Figure 2: Distribution of mechanism of injury of the patients.

Automobile accidents were most common in the winter season while falling from height was more common in the summer (Table 1).

\begin{tabular}{l|c|c|c|c|}
\hline \multicolumn{5}{|c|}{ Table 1: Seasonal correlation by the injury mechanism } \\
Mechanism of injury & Winter & Autumn & Summer & Spring n \\
& $\mathrm{n}(\%)$ & $\mathrm{n}(\%)$ & $\mathrm{n}(\%)$ & $(\%)$ \\
\hline Automobile accidents & $169(56)$ & $52(22.1)$ & $21(7.4)$ & $26(26.8)$ \\
\hline Falls from height & $3(1)$ & $61(26)$ & $130(45.6)$ & $17(17.5)$ \\
\hline Falls from own height & $28(9.3)$ & $21(8.9)$ & $25(8.8)$ & $16(16.5)$ \\
\hline Pedestrians hit by car & $52(17.2)$ & $52(22.1)$ & $40(14)$ & $24(24.7)$ \\
\hline Motorcycle accidents & $34(11.3)$ & $26(11.1)$ & $27(9.5)$ & $4(4.1)$ \\
\hline Bicycle accidents & $4(1.3)$ & $11(4.7)$ & $29(10.2)$ & $7(7.2)$ \\
\hline Others & $12(4)$ & $12(5.1)$ & $13(4,6)$ & $3(3.1)$ \\
\hline
\end{tabular}

Car accidents, falls from a height, motorcycle accidents were observed more frequently in males than females ( $p<0.001)$. Falls from own height, pedestrian hit by a car, other injuries were observed more frequently in females than males ( $p$ $<0.001)$. No statistically significant difference was found between males and females in bicycle accidents $(p=0.124)$ (Table 2). While the mean age of females fell from their own height was 62.79 years, it was 68.46 years for males.

\begin{tabular}{l|c|c|c|}
\hline \multicolumn{4}{|l|}{ Table 2: Gender distribution by injury mechanism } \\
\hline Mechanism of injury & Female $\mathbf{n}(\%)$ & Male $\mathbf{n}(\%)$ & P value \\
\hline Automobile accidents & $43(14)$ & $225(36.8)$ & $<0,001$ \\
\hline Falls from height & $18(5.9)$ & $193(31.5)$ & $<0,001$ \\
\hline Falls from owm height & $53(17.3)$ & $37(6)$ & $<0,001$ \\
\hline Pedestrians hit by car & $150(48.9)$ & $18(2.9)$ & $<0,001$ \\
\hline Motorcycle accidents & $9(2.9)$ & $82(13.4)$ & $<0,001$ \\
\hline Bicycle accidents & $12(3.9)$ & $39(6.4)$ & 0.124 \\
\hline Others & $22(7.2)$ & $18(2.9)$ & 0.003 \\
\hline Others: Fall of heavy object, bus accident, truck accident, etc.
\end{tabular}

According to the Young Burgess classification, 423 (46\%) LC1 was detected most frequently, followed by 211 (23\%) LC2 (Figure 3). 
No statistically significant difference was found between males and females in the Young Burgess classification ( $p>0.05$ ).

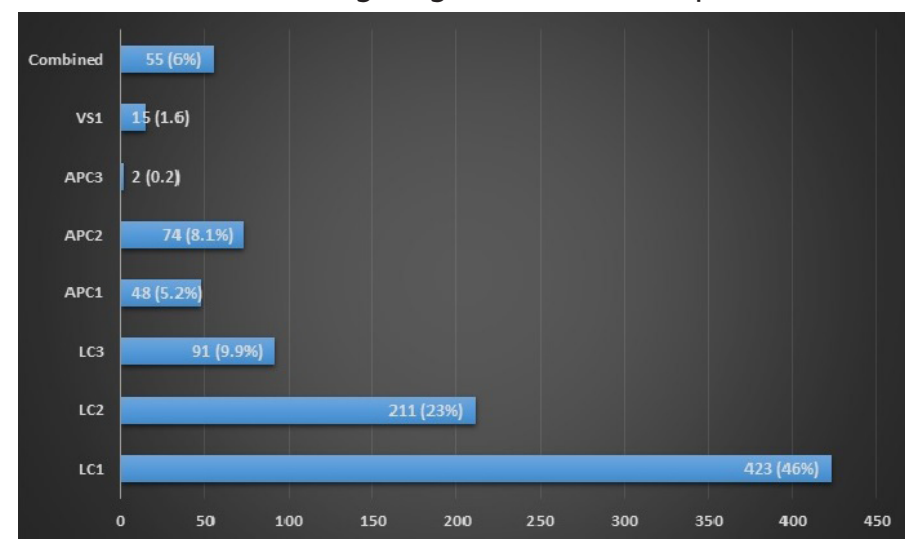

Figure 3: Young Burgess classification

At least one injury was present in 809 (88\%) patients. Pelvic fractures were accompanied by abdominal trauma in 321 (34.9\%) patients and head trauma in 299 (32.5\%) patients (Table 3).

\begin{tabular}{|c|c|}
\hline Associated injury & Total n (\%) \\
\hline Head injury & $299(32.5)$ \\
\hline Maksillofasial injury & $170(18.5)$ \\
\hline Chest injury & $209(22.7)$ \\
\hline Spine injury & $156(17)$ \\
\hline Abdomen injury & $321(34.9)$ \\
\hline Genitourinary injury & $149(16.2)$ \\
\hline Upper extremity injury & $152(16.5)$ \\
\hline Lower extremity injury & $234(25.5)$ \\
\hline Pelvic haemorrhage & $170(18.5)$ \\
\hline Intraabdominal hemorrhage & 105 (11.4) \\
\hline \multicolumn{2}{|c|}{$\begin{array}{l}\text { *Because some patients had more than one associated injury, the } \\
\text { total number of the injuries were higher than the number of patients. }\end{array}$} \\
\hline
\end{tabular}

Eighty (8.7\%) patients died in the ED.

\section{Discussion}

Pelvic fractures are rare in trauma victims; however, associated injuries are common and are among the injuries with high mortality and morbidity. There are a limited number of studies on the epidemiology of pelvic fractures in the literature; recent studies on this subject in Turkey are insufficient. To our knowledge, this study is the largest reported single centre experience in the capital of Turkey, Ankara.

The incidence of pelvic fractures in trauma patients ranges from $2.4 \%$ to $10 \%[6,10,11]$. In our study, the incidence was $9.1 \%$ and was similar to the literature.

In the studies conducted by Chien et al. and Lefaivre et al. in patients with pelvic fractures, the number of female patients was higher than that of males [12,13]. However, in other studies in the general literature, it has been stated that pelvic fractures are observed more in males than in females $[5,8,11,14,15,16]$. In our study, almost two-thirds of the patients with pelvic fractures were constituted by males.

Pelvic fractures are injuries generally observed in the young population under 50 years of age [5]. In studies, the mean age of patients with pelvic fracture ranges between 37-47 years $[6,14,15,16,17]$. The mean age of the patients in our study was $36.5 \pm 14.82$ years and was similar to the literature.

Ježek and Džupa have evaluated 225 patients with pelvic fractures between the ages of 15-95 in their epidemiological studies and have found that the mean age was 49 years in males and 53 years in females [18]. In our study, the mean age of males was $35.1 \pm 13.63$ years, while it was $39.2 \pm 16.63$ years for females. We think this difference between the mean age was due to our society with a high young population.

The vast majority of pelvic fractures occur due to traffic accidents and most frequently occur due to motor collisions vehicle accidents. In the study of Chueire et al. on pelvic ring injuries, $23 \%$ of pelvic fractures were caused by car accidents and $19 \%$ by motorcycle accidents [16]. In the study conducted by Hossain et al. in two tertiary care hospitals, 33.18\% of the causes of pelvic fractures were bus accidents, $21.26 \%$ car accidents, $25.86 \%$ motorcycle accidents [15]. In the study of Chien et al., this rate was $53.4 \%$ automobile and $24.5 \%$ motorbike accident [12]. In our study, similar to the literature, we observed that automobile accident (37.3\%) was the most common cause of pelvic fractures, while motorcycle accidents (10.2\%) were less. It may be due to the motorcycle being a type of transportation that has just begun to be used in our country.

Another important mechanism of trauma in pelvic fracture formation is falls. Falls cause high- and low-energy trauma, depending on the height the patient falls. In the study of Chueire et al., it has been the second most common cause of pelvic fracture with $14 \%$ own height, $18 \%$ fell down from very high points; they found that the majority of fell down from very high points were male construction workers falling from the pier [16]. In our study, falls from height after automobile accidents were the second most common cause of pelvic fracture. Both injury mechanisms are more common in males than in females. The reason for this is that traditionally men are the main workforce in our country, they are frequently involved in social life, and the use of motor vehicles is more common among males than females.

Own height falls are defined as any event in which the patient unintentionally falls to the ground and is traditionally 
considered as a low-impact mechanism associated with minor injuries. However, pelvic fractures can occur with low-energy trauma in elderly patients. Because, with aging, the frequency of osteoporosis increases in both genders, especially in females. In patients over 60 years, $94 \%$ of pelvic fractures are associated with osteoporosis [19]. Krappinger et al. have evaluated pelvic fractures in patients with osteoporosis and have stated that these fractures typically occur as a result of simple falls and that fractures due to high-energy trauma are rare in these patients [20]. Pelvic fractures due to simple falls are more common in females than in males. [8]. In their study, Ježek and Džupa have found that pelvic fractures due to simple falls were more common in elderly patients, males were eight years older than females. They have reported that there were two different patient groups with pelvic fractures [18]. In our study, pelvic fractures due to own height falls were more common in females than males, and the mean age of males was higher than females. We think that this is due to the fact that osteoporosis starts at a relatively earlier age and progresses more severely in elderly women compared to men. Seasonal changes play an important role in trauma admissions. Weather conditions such as precipitation and cloudy skies are known to affect trauma admissions. Parsons et al. have found in their study that trauma admissions increased by $7.9 \%$ in snowy weather [21]. Morgan and Mannering have determined that the probability of severe injury in male drivers under the age of 45 was $17 \%$ on wet/dry surfaces and $42 \%$ on snowy/icy surfaces [22]. Fatal accidents due to adverse weather conditions are relatively higher in winter compared to summer months [23]. Chien et al. have stated in their study that pelvic fractures had a slightly higher incidence rate during the winter months [12]. Similarly, in our study, we found that pelvic fractures in winter are more common than in other seasons. We think that this is due to the increase in automobile accidents due to various reasons such as slippery roads due to precipitation, especially snowfall in winter, limitation of visibility, and drivers driving fast. In our study, falls from height were more common in summer and in males. We think that the acceleration of the construction sector in the summer season and the fact that the construction workers are male contributed to this.

There are two main classification systems for pelvic fractures; Tile and Young-Burgess classification systems. Some studies in the literature have used the Tile classification to classify pelvic fractures; in our study, we used the Young and Burgess classification, which evaluates the fracture pattern by the injury mechanism and anatomical features [9]. The most common type seen in the Young Burgess classification is LC. Coleman et al. and Palmcrantz et al. have found that LC1 (38\%, 46.4\%, respectively) and then LC2 (24\%, 17.9\%, respectively) were detected most frequently in the Young-Burgess classification of pelvic fracture patients $[24,25]$. Similarly, in our study, 423 (46\%) LC1 was found the most, followed by LC2 with 211 [23\%].

The pelvic ring is much stronger than many other bone structures, and a large amount of force is required to break this structure. Therefore, these fractures are indicative of severe injury. The injuries associating with these fractures are common, and the injuries have an effect on mortality [12]. Patients with associated injuries were $45 \%$ in the study of Hossain et al., and 54\% in the study of Chueire et al. [15, 16]. In the study of Coleman et al., $69 \%$ of patients had associated injuries that required surgical intervention during their hospital stay [24]. In the study of Palmcrantz et al., the rate of associated injuries was $99 \%$, but the number of severe injury cases in this study was higher than in other studies [25]. In the present study, $88 \%$ of patients had at least one associated injury. Since our hospital is a tertiary hospital, our rate of referral from other hospitals is high, and the number of patients with associated injuries is correspondingly high.

In various studies, pelvic fractures were associated by $11 \%-$ $37.3 \%$ chest, $12.4 \%-42 \%$ abdominal, $14.8 \%-56 \%$ head injuries $[11,12,26,27]$. In the study of Abdelrahman et al., the extremities and chest were the most common associated injury sites [6]. In our study, associated injuries were abdominal trauma the most, followed by head trauma. We think that the differences in associated injuries in the studies in the literature are due to the age range of the studied patient groups and the difference in trauma mechanisms.

The strength of our study is that it was conducted in a highvolume, tertiary hospital with long-term evaluation. Being a single-center study and its retrospective nature are the limitations of our study.

\section{Conclusion}

The most common mechanisms of pelvic fracture injury are automobile accidents and falls. Associated injuries are frequently observed.

\section{Declaration of conflict of interest}

The authors received no financial support for the research and/or authorship of this article. There is no conflict of interest 


\section{References}

1. Pohlemann T, Stengel D, Tosounidis G, et al. Survival trends and predictors of mortality in severe pelvic trauma: estimates from the German Pelvic Trauma Registry Initiative. Injury. 2011;42:997-1002.

2. Hussami M, Grabherr S, Meuli RA et al. Severe pelvic injury: vascular lesions detected by ante- and post-mortem contrast medium-enhanced CT and associations with pelvic fractures. Int J Legal Med. 2017; 131: 731-38.

3. Hermans E, Biert J, Edwards MJR. Epidemiology of pelvic ring fractures in a level 1 trauma center in the Netherlands. Hip Pelvis. 2017; 29: 253-61.

4. Hodgson S. AO principles of fracture management. Ann R Coll Surg Engl. 2009; 91: 448-9.

5. Ghosh S, Aggarwal S, Kumar V, et al. Epidemiology of pelvic fractures in adults: Our experience at a tertiary hospital. Chin J Traumatol. 2019; 22: 138-41.

6. Abdelrahman $\mathrm{H}$, El-Menyar $\mathrm{A}$, Keil $\mathrm{H}$, et al. Patterns, management, and outcomes of traumatic pelvic fracture: insights from a multicenter study. J Orthop Surg Res. 2020; 15: 249.

7. Davarinos N, Ellanti P, Morris S, et al. Epidemiology of pelvic and acetabular trauma in a Dublin tertiary hospital: a 10-year experience. Ir J Med Sci. 2012; 181: 243-6.

8. Pereira GJC, Damasceno ER, Dinhane DI et al. Epidemiology of pelvic ring fractures and injuries. Rev Bras Ortop. 2017; 52: 260-9.

9. Young JW, Burgess AR, Brumback RJ, et al. Pelvic fractures: value of plain radiography in early assessment and management. Radiology. 1986; 160: 445-51.

10. Riemer BL, Butterfield SL, Diamond DL, et al. Acute mortality associated with injuries to the pelvic ring: the role of early patient mobilization and external fixation. J Trauma. 1993; 35: 671-5.

11. Demetriades D, Karaiskakis M, Toutouzas K, et al. Pelvic fractures: epidemiology and predictors of associated abdominal injuries and outcomes. J Am Coll Surg. 2002; 195: 1-10.

12. Chien LC, Cheng HM, Chen WC, et al. Pelvic Fracture and Risk Factors for Mortality: A Population-Based Study in Taiwan. Eur J Trauma Emerg Surg. 2010; 36: 131-7.

13. Lefaivre KA, Padalecki JR, Starr AJ. What constitutes a Young and Burgess lateral compression-I (OTA 61-B2) pelvic ring disruption? A description of computed tomography-based fracture anatomy and associated injuries. J Orthop Trauma. 2009; 23: 16-21.

14. DzupaV,Chmelová J, PavelkaT, et al. Multicentrická studie pacientů s poranením pánve: základní analýza souboru [Multicentric study of patients with pelvic injury: basic analysis of the study group). Acta Chir Orthop Traumatol Cech. 2009; 76: 404-9.
15. Hossain A, Islam S, Haque Qasem MF, et al. Epidemiology of pelvic fractures in adult: Our experience at two tertiary care hospital in Dhaka, Bangladesh. J Clin Orthop Trauma. 2020; 11: 1162-7.

16. Chueire AG, Filho GC, Santos AF, et al. Fraturas do anel pélvico: estudo epidemiológico. Acta Ortop Bras. 2004; 12: 1-10.

17. Kobbe P, Hockertz I, Sellei RMet al. Minimally invasive stabilisation of posterior pelvic-ring instabilities with a transiliac locked compression plate. Int Orthop. 2012; 36: 159-64.

18. Ježek $M$, Džupa V. Vliv věku pacienta a mechanismu úrazu na typ zlomeniny pánve: epidemiologická studie [The influence of patient age and mechanism of injury on the type of pelvic fracture: epidemiological study). Acta Chir Orthop Traumatol Cech. 2012; 79: 65-8.

19. Küper MA, Trulson A, Stuby FM, et al. Pelvic ring fractures in the elderly. EFORT Open Rev. 2019 Jun 3; 4: 313-20.

20. Krappinger D, Kammerlander C, Hak DJ, et al. Low-energy osteoporotic pelvic fractures. Arch Orthop Trauma Surg. 2010; 130: 1167-75.

21. Parsons N, Odumenya M, Edwards A,et al. Modelling the effects of the weather on admissions to UK trauma units: a crosssectional study. Emerg Med J. 2011; 28: 851-5.

22. Morgan A, Mannering FL. The effects of road-surface conditions, age, and gender on driver-injury severities. Accid Anal Prev. 2011; 43: 1852-63.

23. Saha S, Schramm P, Nolan A, et al. Adverse weather conditions and fatal motor vehicle crashes in the United States, 1994-2012. Environ Health. 2016;1 5: 104.

24. Coleman JR, Moore EE, Vintimilla DR, et al. Association between Young-Burgess pelvic ring injury classification and concomitant injuries requiring urgent intervention. J Clin Orthop Trauma. 2020; 11: 1099-103.

25. Palmcrantz J, Hardcastle TC, Naidoo SRet al. Pelvic fractures at a new level 1 trauma centre: who dies from pelvic trauma? The Inkosi Albert Luthuli Central Hospital experience. Orthop Surg. 2012; 4: 216-21.

26. Gustavo Parreira J, Coimbra R, et al. The role of associated injuries on outcome of blunt trauma patients sustaining pelvic fractures. Injury. 2000; 31: 677-82.

27. Lunsjo K, Tadros A, Hauggaard A, et al. Associated injuries and not fracture instability predict mortality in pelvic fractures: a prospective study of 100 patients. J Trauma. 2007; 62: 687-91. 